\title{
Penegakan Syariat Islam di Aceh dalam Perspektif HAM
}

\author{
Hamdani \\ ${ }^{1}$ Dosen Fakultas Hukum Universitas Malikussaleh
}

\begin{abstract}
Abstrak
Aceh merupakan satu-satunya provinsi di Indonesia yang diberikan keluasan oleh pemerintah pusat untuk mengatur kehidupan dan pembangunan di Aceh sesuai dengan Syariat Islam, peruntukan ini diperkuat dengan keluarnya UU Nomor 44 Tahun 1999 Tentang Keistimewaan Daerah Istimewa Aceh, UU Nomor 6 Tahun 2006 Tentang Pemerintah Daerah. Artinya secara hukum pemerintah Indonesia mengakui dan memberikan atau mengizinkan penerapan Syariat Islam di Aceh. Pada awal penerapan Syariat Islam di Aceh banyak mendapatkan tantangan dan rintangan baik secara internal, yaitu masyarakat yang tinggal di Aceh maupun eksternal yaitu dari luar Aceh juga dunia internasional dan pegiat HAM. Seiring perjalanan waktu pelaksanaan Syariat Islam di Aceh sudah diterima oleh semua pihak. Penegakkan syariat Islam di Aceh merupakan hak kebebasan dasar bukan saja tidak dilarang, melainkan dilindungi oleh Negara Indonesia. Legitimasi penegakan syariat Islam didasarkan pada HAM Internasional dan beberapa Konvenan Hukum Internasional seperti Konvenan DUHAM 1948, konvensi mengenai hakhak sosial, ekonomi, dan budaya (ICCESR) 1996 dan konvensi internasional tentang hak-hak sosial dan politik (ICCPR) 1996. Secara konstitusional UUD 1945 hasil amandemen 1999-2002 juga telah memperkuat argumen hukum internasional. Konsekuensinya negara dan pemerintah Republik Indonesia berkewajiban untuk tidak saja memberikan perlindungan dan perlakuan yang adil dan proposional, melainkan juga memberikan dukungan terhadap penegakan syariat Islam di Aceh sebagai wahana yang memberikan penguatan terhadap Negara Kesatuan Republik Indonesia.
\end{abstract}

Katakunci: Penegakan, Syariat Islam, HAM 


\section{PENDAHULUAN}

Perkembangan kepenjaraan di Indonesia terjadi pada 20 April 1964. Diawali dengan perubahan istilah dari penjara menjadi lembaga pemasyarakatan, hingga pemenuhan hak bagi nara pidana. Dengan pergantian istilah itu sistem rehabilitasi yang diterapkan pun turut berubah. Pada masa sebelumnya, sistem rehabilitasi yang diterapkan mengacu pada prinsip retributif serta penindasan atas kehidupan dan kemerdekaan narapidana, (Romli Atmasasmita, 1982: 16).

Syariat Islam yang terdapat dalam kitab suci al-Qur'an merupakan ajaran yang kaffah (totalitas), diyakini kebenarannya oleh umat Islam diseluruh dunia. Syariat Islam adalah satu sistem ajaran yang telah ditentukan oleh Allah Swt, sebagai khaliq (pencipta) bagi umat manusia selaku hambanya yang wajib tunduk, patuh, taat, dilaksanakan dan menjadi pedoman dalam kehidupan seharihari di dunia ini, sejak dari masa kenabian dan kerasulan. (Thantowi, 2002:7) Oleh karena itu untuk menyelamatkan umat manusia supaya tidak tersesat dalam kehidupan dunia adalah dengan syariat Islam. Hal ini disebabkan syariat Islam merupakan ketentuan dan aturan yang telah ditetapkan oleh Allah Swt, sangat sesuai dengan fitrah manusia, karena Allah Swt, yang menciptakan manusia dan Dia pula yang mengatur dan mengikat manusia dengan hukumhukum-Nya.

Syariat Islam merupakan ajaran yang mengandung prinsipprinsip dasar tentang kehidupan manusia, berkait dengan Akidah, ibadah dan muamalah. Akidah berhubungan dengan keyakinan, keimanan kepada Allah Swt, ibadah berhubungan dengan pelaksanaan ubudiyah kepada Allah Swt, yaitu hubungan manusia dengan Khaliq (hablu minallah) secara vertikal, sedangkan dalam muamalah berhubungan dengan aspek hukum, ekonomi, politik, pendidikan, sosial, budaya dan kekuasaan, hubungan manusia sesama manusia dalam dunia (hablu minannas) secara horizontal. (Thantowi, 2002:7)

Secara komprehensif syariat Islam tidak memisahkan antara kehidupan dunia dengan akhirat, sebagaimana tidak membedakan antara perbuatan manusia sebagai ibadah dan bukan ibadah, sepanjang perbuatan manusia itu untuk kebajikan dan kebaikan bagi dirinya dan orang lain dikatakan ibadah, oleh karena itu dalam Islam dikenal dua ibadah, yaitu ibadah mahdhah (ibadah yang dilakukan manusia secara vertikal) dan qhairu mahdhah (ibadah yang dilakukan manusia secara horizontal). 
Pada dewasa ini ada pemahaman keliru terhadap syariat Islam, dimana mereka menyamakan syariat Islam dengan hukum pidana (jinayat), yaitu penerapan hukuman qishash, rajam dan potong tangansebagai faktor dominan dari pemahaman syariat Islam. Pemikiran seperti sangat sempit, hanya melihat dari satu sisi syariat Islam. Syariat Islam tidak hanya bicara hukum Islam, apalagi hanya dibatasi atau diartikan sebagai hukum pidana saja. Meskipun al-Qur'an menyebut kata syariat sekitar lima kali, konotasinya ternyata jauh lebih dari pada sekedar hukum Islam. (Marzuki, 2006:2)

Syariat secara ammah (umum) terdapat dalam al-Qur'an surah Asy-Syuura ayat 13 bermaksud: Dia telah mensyariatkan bagi kamu tentang agama apa yang diwasiatkan-Nya kepada Nuh, dan apa yang telah Kami wahyukan kepadamu, dan apa yang telah kami wasiatkan kepada Ibrahim, Musa, dan Isa yaitu, Tegakkanlah agama dan janganlah kamu berpecah belah tentangnya. Dalam alQur'an di ayat lain kata syariah dimaksudkan adalah sebagai ketentuan hukum, seperti disebutkan dalam surah al-Maidah ayat 48 .

Syariat adalah tugas umat manusia secara menyeluruh meliputi, akhlak, moral, kesopanan, teologi, etika pembinaan umat, spiritual, ibadah formal, kesehatan dan ritual yang rinci. Syariat Islam mencakup semua aspek hukum publik dan privat. (an-Naim, 1999: 26)

Menurut Maududi, ciri-ciri syariat antara lain menentukan arah bagi pengaturan perilaku individu maupun kehidupan umat manusia secara kolektif. Petunjuk itu mencakup berbagai segi seperti ritual keagamaan, sifat-sifat kepribadian, moral, kebiasaan hubungan keluarga, kehidupan sosial dan urusan ekonomi, administrasi, hak dan kewajiban warga negara, sistem peradilan, hukum perang dan perdamaian serta hubungan internasional. (Maududi, 1975: 49) Dengan demikian dapat dikatakan syariat mencakup seluruh aspek kehidupan manusia.

Pemikiran yang menyamakan syariat Islam dengan hukum pidana tidak hanya disebabkan kekacauan metodologi berfikir sebahagian umat Islam, juga disebabkan provokasi pemikiran orientalis yang menempatkan ajaran Islam dari sanksi hukum atau legal formal. Untuk keluar dari cara berfikir kritis dan inovatif masih memerlukan waktu panjang. Miskonsepsi tersebut juga didukung oleh adanya pandangan bahwa penyebaran Islam dilakukan dengan menggunakan pedang (kekerasan). Implikasi dari pemahaman tersebut masih tetap menjadi stigma masyarakat di berbagai negara, 
terutama ketika umat Islam digiring kearah berfikir secara liberal dan sekuler, oleh sebab itu meskipun pro kontra tentang penegakan syariat Islam masih berlangsung, baik secara internal sesama umat Islam maupun eksternal sesama masyarakat Aceh. Dalam semangat HAM, perjuangan menerapkan syariat Islam di Aceh sejauh tidak bertentangan dengan konstitusi, maka tidak ada halangan untuk dilaksanakan. Hal ini bukan saja karena pemerintah dan rakyat Aceh tidak memiliki hak untuk menghambat pelaksanaan syariat Islam di Aceh, melainkan sebaliknya pemerintah berkewajiban memberikan perlindungan terhadap perjuangan penegakan syariat Islam, sebab ia tergolong sebagai hak-hak fundamental dan kebebasan umat manusia khususnya kaum muslimin di Aceh.

\section{METODE PENELITIAN}

Berdasarkan latar belakang masalah diatas maka rumusan masalah yang diajukan adalah bagaimana tinjauan dalam Perspektif HAM terhadap pelaksanaan Syariat Islam di Aceh?. Harapannya penelitian ini nantinya dapat memberikan gambaran komprehensif tentang Islam dan HAM yang dikaitkan dengan penerapan syariat Islam di Aceh.
Dalam penelitian ini, penulis menggunakan pendekatan kualitatif-deskriptif yaitu dengan cara mendeskripsikan hubungan ataupun pertentangan antara konsep HAM yang dianut dunia saat dengan dengan Hukum Islam yang berlaku di Aceh.

\section{HASIL DAN PEMBAHASAN}

\subsection{Syariat Islam di Indonesia}

Syariat Islam diterima di Indonesia disebabkan oleh beberapa alasan. Alasan pertama adalah sejarah, dimana Islam masuk ke Indonesia sejak abad ke-7 (berdasarkan catatan Marcopollo) atau sekitar abad ke-11 berdasarkan prasasti yang ada di Indonesia. Hal tersebut menunjukkan bahwasanya Islam telah mengakar di Indonesia sejak lama sehingga mempengaruhi kehidupan masyarakat Indonesia.

Alasan kedua adalah penduduk. Menurut sensus, 238 juta jiwa penduduk Indonesia adalah Islam, sekitar $70 \%$ (sensus tahun 2010), sehingga jelas mayoritas penduduk Indonesia adalah beragama Islam. Hal tersebut menyebabkan syariat Islam mudah diterima di Indonesia.

Alasan ketiga adalah yuridis, dimana hukum Islam yang mengatur hubungan manusia dengan manusia lain dan kebendaan dalam masyarakat, menjadi hukum posi- 
tif yang berdasarkan pada peraturan perundang-undangan. Materimateri hukum Islam merupakan bagian dari hukum positif Indonesia sebagaimana yang dinyatakan oleh ordonansi dan peraturan pemerintah yang mengatur peradilan agama antara lain pada undangundang pokok perkawinan UU No. 1 tahun 1974, UU No.41 tahun 2004 tentang wakaf, UU No.38 Tahun 1999 tentang pengelolaan zakat, pasal-pasal dalam KUHPerdata yang mengatur tentang kewarisan, serta peraturan-peraturan lainnya.

Alasan yang terakhir adalah konstitusional, pada bab agama, dalam Pasal 29 ayat (1) UUD 1945 dinyatakan bahwa Negara (Republik Indonesia) berdasarkan atas Ketuhanan Yang Maha Esa. Atas dasar inilah dalam NKRI tidak boleh berlaku sesuatu atau bertentangan dengan kaidah Islam bagi umat Islam, kaidah Nasrani bagi umat Nasrani, kaidah Hindu bagi umat Hindu, dan kaidah Budha bagi umat Budha, serta NKRI wajib menjalankan syariat Islam bagi umat Islam, ajaran Nasrani bagi umat Nasrani, dan seterusnya, dimana untuk menjalankannya tersebut diperlukan perantaraan kekuasaan negara.

Secara institusi hak untuk penegakan syariat Islam bagi kaum muslimin di Indonesia tidak dapat terbantahkan sejak adanya amandemen UUD 1945 yang dilak- sanakan oleh Majelis Permusyawaratan Rakyat (MPR) sejak tahun 1999-2002. Dampak dari amandemen tersebut bukan sekedar sistem kekuasaan pemerintah yang sentralistik hilang, melainkan juga telah memberikan makna subtansial tentang kebebasan dasar kehidupan beragama.

Kenyataan tekstual tentang jaminan penegakan syariat Islam dalam UUD 1945 tidak berhasil diperjuangkan dalam pasal 29 UUD 1945 sebagai suatu putusan politik yang final. Akan tetapi realitas politik dan sosiologis masyarakat Islam di beberapa Propinsi dan Kabupaten bertolak belakang. Pemerintah Pusat terbukti tidak mampu mencegah Propinsi dan Kabupaten yang mendeklarasikan penegakan syariat Islam.

Meskipun demikian perjuangan penegakan syariat Islam hendaknya dilakukan dengan selalu berpegang pada asas musyawarah dan mufakat, sehingga kewajiban negara untuk memberikan jaminan dan perlindungan secara memadai menjadi jelas dan sinifikan. Dalam pasal 28 ayat 2 UUD 1945 dinyatakan bahwa: dalam menjalankan hak dan kebebasannya, setiap orang wajib tunduk pada pembatasan yang ditetapkan undangundang dengan maksud sematamata untuk menjamin pengakuan serta penghormatan atas hak dan kebebasan orang lain dan untuk 
memenuhi tuntutan yang adil, sesuai dengan pertimbangan moral, nilai-nilai agama, keamanan dan ketertiban umum, dalam suatu masyarakat demokratis.

Konsekuensi kehidupan beragama yang patuh pada persoalan HAM, tidak sekedar mewajibkan warga negara Muslim menghormati perbedaan yang timbulsesama pemeluk agama Islam, melainkan juga dapat menghormati kehadiran pemeluk agama-agama lain. Meskipun demikian, kebebasan agama akan menjadi pilar perdamaian jika azas kerukunan hidup beragama telah menjadi sasaran dari penegakan syariat Islam. Oleh karena itu menjadi keniscayaan jika kebebasan beragama harus bersifat anti pemaksaan atas keyakinan orang lain. Dengan demikian adanya keseimbangan sikap antara penegakan syariat Islam sebagai hal dalam kebebasan dasar, juga terikat dengan kewajiban penghormatan atas mereka yang belum menghendaki penerapan syariat Islam. Dalam pasal 29 ayat 1 dan 2 dinyatakan bahwa :

(1) Negara berdasar atas Ketuhanan Yang Maha Esa.

(2) Negara menjamin kemerdekaan tiap-tiap penduduk untuk memeluk agamanya masingmasing dan beribadat menurut agamanya dan kepercayaannya itu.
(3) Selain itu, bagi kaum muslimin, pasal tersebut juga mengandung arti bahwa negara memberikan jaminan dan perlindungan atas terselenggaranya praktek dan kehidupan beragamasesuai dengan keyakinannya.

Dalam konteks perjuangan penegakan syariat Islam, ayat tersebut dapat diartikan bahwa kaum muslimin selain memiliki hak dan kebebasan dalam merealisasikan ajaran agamanya secara kaffah,negara juga dapat dipandang melanggar hak konstitusional jika pemerintah atau warga negara lainnya menghambat dan melarang kaum muslimin untuk menerapkan syariat Islam. Kata-kata: "...untuk beribadat menurut agamanya dan kepercayaannya" dalam pandangan Islam bukan semata-mata kebebasan melakukan ibadah ritual semata. Islam tidak memaknai ajaran dan perilaku agama identik dengan ibadah atau ritualistik, dan pekerjaan bernegara itu identik dengan non ibadah.

Penegakan syariat Islam sebagaimana mengacu pada pasal 29 tersebut jelas memperkuat tuntutan konstitusional untuk memperoleh perlindungan dan dukungan dari negara, dengan koridor sistem hukum yang berlaku dan menjadi kesepakatan bersama bangsa Indonesia secara keseluruhan. Hal ini juga senada dengan pandangan 
Nathan Lerner ketika ia menafsikan tentang hak dan kebebasan beragama dalam sembilan parameter. (Marzuki, 2006:115)

\subsection{Islam dan Hak Asasi Manusia Hak asasi manusia dalam Is-} lam dapat ditelusuri dari ajaran tauhidnya yang mengandung arti hanya satu Pencipta bagi alam semesta. Ajaran dasar dalam Islam adalah la ilaaha illa Allah (tiada tuhan selain Allah, tiada Pencipta selain Allah). Seluruh apa yang ada di langit dan dipermukaan bumi beserta diantara keduanya adalah ciptaan Allah Swt. Dengan demikian ajaran tauhid ide persamaan dan persaudaraan seluruh manusia. (Q.S. 49:10). Ajaran tauhid juga mencakup ide persamaan dan persatuan seluruh makhluk, tumbuhtumbuhan, hewan dan manusia (tegasnya Islam mencakup ide prikemanusiaan dan prikemakhlukan).

Ide prikemakhlukan terlihat dimana adanya larangan bagi manusia untuk tidak bersikap sewenang-wenang, tetapi bersikap baik terhadap makhluk lain. Islam melarang manusia menyakiti binatang dan manusia dituntut untuk menebarkan kasih sayang kepada semua makhluk Allah Swt. Kasih sayang ini tidak terbatas hanya kepada manusia juga kepada komunitas binatang.
Ide prikemanusiaan sebagaimana disebutkan dalam alQur'an (Q.S. 4:1, 7:189, dan 49:13) dijelaskan bahwa seluruh manusia adalah bersaudara, mereka diciptakan dari sumber yang satu yakni Allah Swt. Rasulullah Saw, bersabda "Wahai manusia, sesungguhnya Tuhan kamu adalah satu dan bapak kamu adalah satu. Катu semua adalah keturunan Adam dan Adam berasal dari tanah, yang paling mulia di antara kamu di sisi Allah adalah yang paling bertaqwa. Tidaklah lebih mulia orang Arab dari yang bukan Arab, atau sebaliknya, dan perbedaan itu hanyalah terletak pada taqwanya" (H.R. Muslim) Ayat dan hadits di atas menjelaskan tidak ada perbedaan antara sesama manusia, mereka berasal dari sumber yang satu, sekalipun secara sosiologis terdiri dari berbagai bangsa, berbagai bahasa, perbedaan warna kulit, dan agama yang berlainan. Oleh karena manusia bersaudara maka di antara mereka harus ada rasa dan sikap saling mengasihi sesama. Rasulullah Saw, juga menjelaskan "Cintailah saudaramu sebagaimana engkau mencintai dirimu sendiri" (H.R. Bukhari dan Muslim).

Mufassirin menjelaskan, surah al-Hujurat ayat 13 di atas bahwa antara manusia yang saling bersaudara dan saling mengasihi tidak ada perbedaan kedudukan. Perbedaan hanya pada tingkat ke- 
taqwaan kepada Allah Swt. Orang yang paling tinggi kedudukannya disisi Allah adalah mereka yang bertaqwa, demikian sebaliknya yang paling sedikit kebajikannya, rendah kedudukannya disisi Allah Swt. Atas dasar itu, perbedaan satu-satunya yang ada antara semua manusia yang bersaudara dan sama derajatnya hanyalah terletak pada tinggi dan rendahnya moral seseorang.

Manusia yang bersaudara, saling mengasihi dan sama derajatnya tidak boleh diperbudak oleh manusia lain (Q.S. 90:13 dan 2:279). Manusia dalam Islam adalah manusia yang bebas dalam kemauan dan perbuatannya, bebas dari tekanan dan paksaan, bebas dari eksploitasi dan bebas dari pemilikan orang lain. Manusia dalam Islam hanya milik Alaah Swt dan hamba-Nya. Ketika Khalifah Umar bin Khattab mendengar anak gubernurnya di Mesir Amr bin Ash, bersikap kasar kepada salah seorang penduduk Mesir, maka ia berkata: "sejak kapan memperbudak manusia, sedang mereka dilahirkan oleh ibu-ibu mereka dalam keadaan bebeas".

Sejalan dengan ajaran kebebasan dalam Islam, terdapat ajaran "tidak ada paksaan dalam agama" (Q.S. 2:256). Oleh karena itu dakwah dalam Islam menyampaikan ajaran Allah Swt kepada manusia dan tidak memaksa orang lain masuk Islam (Q.S. 10:99). Allah Swt mengingatkan Nabi Saw "Maka berilah peringatan, karena sesungguhnya kamu hanyalah orang yang memberi peringatan. Kamu bukanlah orang yang berkuasa atas mereka" (Q.S. 88:21-22). Juga dijelaskan dalam Islam prinsip hubungan antar sesama pemeluk agama yakni, Lakum dinukum waliya diin"(berpeganglah (bagimu)kamu pada agama mu, dan aku berpegang atau bagi ku agama ku)" (Q.S. 109:6). Ini membuktikan toleransi beragama adalah salah satu ajaran dasar dalam Islam.

Dari ajaran persamaan, persaudaraan dan kebebasan manusia di atas, maka timbullah kebebasankebebasan manusia. Selain kebebasan dari perbudakan dan kebebasan beragama, juga kebebasan dari kekurangan, kebebasan dari rasa takut, kebebasan mengeluarkan pendapat, kebebasan bergerak, kebebasan dari penganiayaan dan lain-lain. Dari itu lahirlah hakhak asasi manusia seperti hak hidup, hak memiliki harta, hak pendidikan, hak berbicara, hak berfikir, hak mendapatkan pekerjaan, hak memperoleh keadilan, hak persamaan, hak kekeluargaan dan lain-lain.

Dalam Islam kebebasan dan hak asasi yang dimiliki manusia tidaklah bebas tanpa batas atau bersifat absolut. Keabsolutan hanyalah milik Allah Swt, sedangkan 
makhluk-Nya terbatas atau relatif. Manusia juga mempunyai kewajiban yang diwajibkan oleh Allah, yaitu patuh pada perintah dan larangan-Nya. Larangan disini manusia tidak berbuat kerusakan di muka bumi (Q.S. 7:56) dan perintah, manusia berbuat baik, tidak mengutamakan kepentingan pribadi dan tidak mengabaikan kepentingan orang lain dan kepentingan umum.

Dalam ajaran Islam, individu tidak berada di atas masyarakat, masyarakat juga tidak berada di atas individu. Keduanya berjalan seiring dan seimbang dalam arti kepentingan individu tidak boleh diabaikan, dan kepentingan masyarakat tidak boleh dikalahkan oleh kepentingan individu. Kebebasan dalam Islam mempunyai batas-batas seperti kebebasan mengeluarkan pendapat tidak boleh melanggar kepentingan umum. Kebebasan mengumpulkan harta tidak boleh merugikan masyarakat dan kebebasan mengelola alam tidak boleh menimbulkan kerusakan lingkungan dan malapetakabagi masyarakat umum (Q.S. 5:33 dan 30:41).

Kebebasan berpendapat sejak lama dikenal dalam Islam, ini dapat ditelusri dari kehidupan para shahabat dengan Rasulullah Saw, seperti dalam peristiwa perang Badar, Nabi Saw, memilih suatu tempat khusus yang dianggap strategis untuk menyerang musuh, namun shahabat menyarankan tempat lain, dan Nabi menyetujuinya, karena ternyata tempat itu lebih strategis. (H.R. Bukhari).

Dari uraian di atas jelas bahwa hak asasi dalam Islam berbeda dengan hak asasi menurut pengertian umum. Seluruh hak merupakan kewajiban bagi negara maupun individu yang tidak boleh diabaikan. Rasulullah saw bersabda: "Sesungguhnya darahmu, hartamu dan kehormatanmu haram atas kamu." (HR. Bukhari dan Muslim). Oleh itu negara tidak saja menahan diri dari melanggar hakhak asasi, melainkan mempunyai kewajiban memberikan perlindungan dan menjamin hak-hak ini.

Sebagai contoh, negara berkewajiban menjamin perlindungan sosial bagi setiap individu tanpa ada perbedaan jenis kelamin, tidak juga perbedaan muslim dan nonmuslim. Islam tidak hanya menjadikan kewajiban negara, melainkan negara diperintahkan untuk berperang demi melindungi hakhak ini, seperti kaum muslimin bersama Abu Bakar ketika diangkat menjadi khalifah memerangi orang-orang yang tidak mau membayar zakat. Negara juga menjamin tidak ada pelanggaran terhadap hak-hak ini dari pihak individu. Sebab pemerintah mempunyai tugas sosial yang apabila tidak dilaksanakan berarti tidak berhak un- 
tuk tetap memerintah. Allah berfirman: "Yaitu orang-orang yang jika Kami teguhkan kedudukannya di muka bumi, niscaya mereka menegakan shalat, menunaikan zakat, menyuruh berbuat ma'ruf dan mencegah perbuatan munkar. Dan kepada Allah-lah kembali semua urusan." (QS. 22: 4).

Jaminan pertama hak-hak pribadi dalam sejarah umat manusia adalah dijelaskan Al-Qur'an: "Hai orang-orang yang beriman, janganlah kamu memasuki rumah yang bukan rumahmu sebelum meminta izin dan memberi salam kepada penghuninya... ." (QS. 24: 27-28). Dalam menjelaskan ayat ini, Ibnu Hanbal dalam Syarah Tsulatsiyah Musnad Imam Ahmad menjelaskan bahwa orang yang melihat melalui celah-celah pintu atau melalui lubang tembok atau sejenisnya selain membuka pintu, lalu tuan rumah melempar atau memukul hingga mencederai matanya, maka tidak ada hukuman apapun baginya, walaupun ia mampu membayar denda. Jika mencari aib orang dilarang kepada individu, maka itu dilarang pula kepada negara. Penguasa tidak dibenarkan mencari-cari kesalahan rakyat atau individu masyarakat. Rasulullah saw bersabda: "Apabila pemimpin mencari keraguan di tengah manusia, maka ia telah merusak mereka."
Imam Nawawi dalam Riyadus-Shalihin menceritakan ucapan Umar: "Orang-orang dihukumi dengan wahyu pada masa Rasulullah Saw. Akan tetapi wahyu telah terhenti. Oleh karenanya kami hanya menghukumi apa yang kami lihat secara lahiriah dari amal perbuatan kalian." Muhammad AdDaghmi dalam At-Tajassus wa Ahkamuhu fi Syari'ah Islamiyah mengungkapkan bahwa para ulama berpendapat tindakan penguasa mencari-cari kesalahan untuk mengungkap kasus kejahatan dan kemungkaran, menggugurkan upayanya dalam mengungkap kemungkaran itu. Para ulama menetapkan bahwa pengungkapan kemungkaran bukan hasil dari upaya mencari-cari kesalahan yang dilarang agama. Perbuatan mencaricari kesalahan sudah dilakukan manakala muhtasib (polisi syariat) telah berupaya menyelidiki gejalagejala kemungkaran pada diri seseorang, atau dia telah berupaya mencari bukti yang mengarah kepada adanya perbuatan kemungkaran. Para ulama menyatakan setiap kemungkaran yang belum tampak bukti-buktinya secara nyata, maka kemungkaran itu dianggap kemungkaran tertutup yang tidak dibenarkan bagi pihak lain untuk mengungkapkannya. Jika tidak, maka upaya pengungkapan ini termasuk tajassus yang dilarang agama. 
Sejak gelombang informasi tanpa batas sampai ke dunia, isuisu utama demokrasi dan HAM telah menawarkan manfaat-manfaat yang dapat dijadikan acuan dasar bagi umat Islam, sehingga negaranegara Islam dimanapun di dunia, dalam era globalisasi sekarang ini tidak mungkin dapat menyembunyikan dirinya dari sistem pemerintahan yang represif otoriter.

Lebih lanjut kecenderungan umum di kalangan negara-negara Islam telah muncul untuk merumuskan sebuah hak-hak asasi Islam yang berbeda dari konsep Barat. Ada tiga kelompok di dunia Islam dalam menanggapi HAM. Pertama, kelompok Sultan Hussein, pemimpin kelompok Syiah Iran, membuat tiga katagori dalam menganalisa Deklarasi Universal tentang hak-hak asasi manusia jika dikaitkan dengan ajaran Islam, yaitu pertama deklarasi hak-hak asasi manusia jika dibandingkan dengan prinsip-prinsip Islam tenyata lebih baik, beliau menyatakan Islam memiliki kedudukan yang lebih tinggi dan tidak ada yang lebih tinggi dari pada Islam. Kedua,ada ketentuan-ketentuan yang dapat diterima oleh orang Islam, atau setidaknya tidak dapat ditolak. Ketiga, ada ketentuan-ketentuan yang tidak dapat diterima oleh orangorang Islam. (Syahrizal, 2002: 8)

Kelompok kedua, mengadakan reformasi dan transformasi melalui peraturan Islam yang diperbaharui secara menyeluruh, untuk memenuhi kebutuhankebutuhan sosial masyarakat.

Kelompok ketiga, adalah kelompok moderat yang memberikan suatu solusi tentang HAM dengan acuan dari ajaran Islam dan kebutuhan zaman modern. Kelompok ini yang termasuk dalam kategori Deklarasi Islam Universal tengan hak-hak asasi manusia yang diterbitkan oleh Dewan Islam pada Konferensi Islam di Mekkah tahun 1981. Deklarasi ini berisi 23 pasal dan menampung dua kekuatan besar, yaitu keimanan kepada Allah dan pembentukan tatanan Islam.

Dalam deklarasi ini dijelaskan bahwa penguasa dan rakyat adalah sebuah subjek dan sama di depan hukum (pasal IV.a). Setiap individu dan setiap orang wajib berjuang dengan segala cara yang tersedia untuk melawan pelanggaran dan pencabutan hak (Pasal IV c dan d). Setiap orang tidak hanya memilki hak, melainkan juga mempunyai kewajiban memprotes ketidakadilan (Pasal IV b). Setiap muslim berhak dan berkewajiban menolak untuk menaati setiap perintah yang bertentangan dengan hukum, siapapun yang memerintahkannya (Pasal IV c). Setiap wanita yang telah menikah berhak mencari dan mendapatkan perceraian sejalan dengan syarat-syarat 
hukum (Pasal XX c). (Syahrizal, 2002: 8)

Dalam kondisi yang kini cenderung semakin memiliki keterpautan secara global, maka kedudukan hak-hak dasar dan kebebasan manusia tidak dapat ditawar lagi. Realisasi satu ideologi tertentu, termasuk syariat Islam dalam ranah publik tidaklah bertentangan dengan Hak Asasi Manusia (HAM). Kebebasan dasar yang diakui oleh negara justru wajib dilindungi. Karena itu syariat Islam yang dipandang sebagai spirit perjuangan umat Islam perlu dikembangkan, mengingat adanya jaminan dari Deklarasi Universal tentang HAM 1948.

Penegakan syariat Islam bagi kaum muslimin di dunia telah dengan jelas mendapat pengaturan dari HAM internasional. Hak beragama dan Hak Kebebasan untuk melakukan segala aktivitas beragama dapat ditemukan dalam beberapa dokumen penting.

Dalam deklarasi universal tentang HAM 1948, dalam pasal 2 ditegaskan bahwa setiap orang memiliki semua hak dan kebebasan sebagaimana diatur dalam deklarasi ini, tanpa ada perbedaan untuk alasan, seperti ras, warna kulit, bahasa, agama, pandangan politik atau kebangsaan atau asalusul sosial, kekayaan, kekuasaan dan status lainnya.
Perlindungan yang tegas mengenai kebebasan beragama, dalam hukum HAM internasional adalah terkait dengan konsep religios intolerant (sikap tidak ada toleransi) yaitu kondisi minoritas tidak boleh menumbuhkan adanya perlakuan diskriminasi. Sejak tahun 1967 rancangan perjanjian internasional telah menegaskan tentang pembatasan terhadap segala bentuk perlakuan yang tidak toleran terhadap agama, termasuk larangan yang bertentangan dengan kebebasan terhadap pemeluk agama.

Secara umum dalam pasal 3 Draft Konvensi menyebutkan:

a. Bahwa kebebasan untuk memeluk atau tidak memeluk, atau mengubah agamanya merupakan hak asasi.

b. Kebebasan untuk mengepresikan perilaku keagamaan atau kepercayaan baik secara pribadi atau bersama-sama, baik secara privat atau umum, merupakan subyek yang tidak boleh diperlakukan secara diskriminatif.

Dalam pasal 3 bagian 3, ditegaskan negara-negara wajib untuk melindungi siapapun di bawah yuridiksinya, meliputi;

a. Kebebasan untuk beribadah atau mengumpulkan suatu seremonial bersama

b. Kebebasan untuk mengerjakan, untuk melakukan disimi- 
nasi, dan mempelajari ajaran agama dengan menggunakan bahasa yang suci dengan tradisi menulis, mencetak, mempublikasikan buku, dan sebagainya.

c. Kebebasan untuk mengamalkan ajaran agama dan keperluannya dengan membangun institusi pendidikan, amal dana bantuan yang diselenggarakan di tempat umum.

d. Kebebasan untuk mematuhi peribadatan, makanan dan praktek keagamaan dan untuk memproduksi, menjalankan impor-eksport barang-barang, makanan dan fasilitas yang biasanya dipergunakan untuk pengamalan ajaran agama.

e. Kebebasan melakukan kunjungan haji atau perjalanan terkait dengan keyakinan keagamaan, baik di dalam maupun di luar negeri.

f. Perlakuan dengan hukum yang setara terhadap tempattempat peribadatan, aktivitas dan upacara keagamaan dan tempat-tempat untuk penguburan mayat, sesuai dengan keyakinan agamanya.

g. Kebebasan berorganisasi dan memelihara hubungan organisasi secara lokal, nasional dan internasional terkait dengan kegiatan agama, dan melakukan komunikasi dengan penganut agama lain. h. Kebebasan pemaksaan untuk melakukan sumpah menurut ketentuan agamanya.

Meskipun perjanjian ini belum disahkan oleh $\mathrm{PBB}$, beberapa negara seperti Amerika Serikat dan Jerman telah menerapkannya sesuai dengan kaidah hukum kebiasaan. ( Brownlie, 1971: 19) Jika proses penerapan ini terus dipatuhi, besar kemungkinan nantinya menjadi hukum kebiasaan internasional.

Sejak 1981, Majelis Umum PBB telah mengadopsi pernyataan tentang berbagai larangan pembatasan atau segala bentuk intoleransi dan diskriminasi. Kemudian, Komisi Penyidik PBB telah menjadi Tim Pelaporan. Salah satu cacatan penting dari Tim Pelaporan, tahun 1983, lahirnya hukum kebiasaan untuk persoalan diskriminasi keagamaan wajib menyesuaikan dengan prinsip-prinsip yang diatur dalam Rancangan Deklarasi. (Robertson, 1992:92)

Apabila kemerdekaan beragama diletakkan sebagai hak fundamental, maka bentuk larangan apapun atas hak-hak dasar akan dinyatakan sebagai bertentangan dengan HAM Internasional.

Kebebasan sebagaimana dikumandangkan, yaitu freedom of expression, of association, of religion, freedom of fear, want and hunger, merupakan kewajiban negara untuk melindunginya dengan 
beberapa alasan, Pertama, perjanjian internasional tentang hak-hak ekonomi, sosial dan budaya1966, berbunyi setiap orang memiliki hak dan kemerdekaan untuk berfikir, berpenghayatan, kepercayaan, termasuk didalamnya memiliki lembaga menganut suatu agama atau keyakinan sesuai pilihannya, kebebasan, apakah pribadi atau kelompok dengan yang lainnya, baik secara privat dan publik, untuk menunjukkan keberagaman atau kepercayaan dalam beribadah, pengamalan, dan praktek pengajaran. Kedua, deklarasi majelis umum PBB tanggal 16 Desember 1996, mulai berlaku efektif 3 Januari 1976 dan 23 Maret 1976 diantaranya berbunyi; tidak seorangpun dapat diperlakukan secara paksa untuk mengurangi kebebasan menganut suatu agama atau kepercayaan atas pilihannya. Kebebasan mewujudkan suatu agama atau kepercayaan terdapat pembatasan hanya apabila ada pengaturan dari hukum nasional, yang diperlukan mengingat perlindungannya terhadap keamanan publik, ketertiban, kesehatan, moral atau kebebasan lainnya. (Asfar, tt:111)

Menurut Lerner beberapa ketentuan mengenai hak-hak dasar keagamaan pada saat ini telah merefleksikan kebiasaan hukum internasional, dan ketentuan mengenai pembatasan perlakuan diskriminatif atas dasar agama, atau pelanggaran genocida terhadap kelompok agama tertentu, tergolong pada perbuatan pelanggaran HAM berat atau tergolong IusCogen. (Lerner, tt: 121) Persoalannya jika timbul pandangan bahwa hak penerapan suatu ajaran agama berada dalam ranah politik, maka kerangka HAM yang berkembang dalam dikursus universal dengan kultur relativisme tidak dapat diabaikan.

Dengan memperhatikan kondisi politik dan pemerintahan yang belum sepenuhnya mau menerima demokrasi dan HAM yang masih tergantung proses internasionalisasi, maka tidak dapat dipungkiri telah berpengaruh terhadap perkembangan HAM di negara-negara Asia. Akibatnya, keberadaan HAM yang timbul di negaranegara Asia Tenggara misalnya, tumbuh dan berkembang dalam kondisi yang berbeda-beda.

Secara demikian, tidaklah mengherankan jika gerakan fenomental penegakan syariat Islam sulit dipahami dari perspektif HAM. Ahmad an-Naim menegaskan bahwa pembelaan terhadap HAM di dunia Muslim akan efektif jika dipahami dalam konteks ajaran Islam. Akan tetapi, mereka perlu mendefinisikan sikap pada penafsiran historis yang khusus dari segi hukum Islam yang dikenal sebagai syariat. Muslim diwajibkan dalam urusan keyaki- 
nan, kepercayaan dan perbuatan, baik privat maupun publik, sesuai dengan petunjuk ajaran Islam, namun terdapat ruang yang memunculkan perbedaan dalam konteks modern. (an-Naim, 1996:210)

Oleh karena itu, apabila dunia Islam terkesan banyak melakukan pelanggaran HAM, maka itu terkait dengan kurangnya kesadaran tentang legitimasi budaya, terkait nilai-nilai standar internasional dalam masyarakat. Sejauh ini prinsip-prinsip standar tersebut dipahami sebagai suatu yang asing, atau yang menyimpang dari nilai-nilai masyarakat yang ada.

Bagi pendukung penegakan syariat Islam sepatutnya tidak saja menyuarakan penegakan syariat Islam dalam konteks perdata dan kemasyarakatan, melainkan juga dalam proses yang lebih luas termasuk hal-hal sipil dan politik. Justru kalau ada kekuatan negara atau non negara terlibat dalam menghambat penegakan syariat Islam, akan dipandang sebagai penentang atas HAM sebagaimana dirumuskan dalam Perjanjian Internasional tentang hak-hak sipil dan politik.

\subsection{Penegakan Syariat Islam di Aceh}

Sistem Syariat dalam pengertian etimologi adalah jalan yang harus ditempuh. Dalam arti terminologi (teknis), syariat adalah se- perangkat norma ilahi yang mengatur hubungan manusia dengan Allah, hubungan manusia dengan manusia lain dalam kehidupan sosial, hubungan manusia dengan benda dan alam lingkungan hidupnya. (Daud Ali, 2006:34) Norma ilahi tersebut berupa ibadah yang mengatur tata cara dan upacara hubungan langsung dengan Tuhan, dan muamalah yang mengatur hubungan manusia dengan manusia lain dan keperdataan dalam masyarakat.

Ibadah berkaitan dengan rukun Islam, yakni syahadah, sholat, zakat, puasa, dan haji. Dalam norma tersebut, tidak boleh ada penambahan dan pengurangan sebab tata hubungan dengan Tuhan telah pasti ditetapkan oleh Allah SWT sendiri yang dijelaskan kemudian secara rinci oleh rasulNya. Dengan demikian, dalam ibadah tidak diperbolehkan adanya pembaruan atau bid'ah, yaitu proses yang membawa perubahan (penambahan atau pengurangan) mengenai kaidah, susunan, dan tata cara beribadah sesuai dengan perkembangan zaman.

Muamalah, hanya pokokpokoknya saja yang ditentukan dalam Al-Qur'an dan as-Sunnah, sedangkan perinciannya terbuka bagi akal manusia yang memenuhi syarat untuk berijtihad untuk mengaturnya lebih lanjut dalam menentukan kaidahnya menurut 
ruang dan waktu (yang dimanifestasikan berupa hukum positif). Kaidah-kaidah muamalah terbagi atas kaidah yang mengatur hubungan perdata dan kaidah-kaidah yang mengatur hubungan publik. Dalam hubungan perdata terdapat hukum munakahat atau hukum perkawinan, hukum kewarisan, dan hukum perdata lainnya, sedangkan dalam hubungan publik terdapat hukum jinayat atau hukum pidana, khilafah atau alahkam as-sulthaniyah atau hukum tata Negara, syiar atau hukum internasional, serta mukhasamat atau hukum acara.

Ilmu khusus yang memahami, mendalami, dan merinci syariat, baik ibadah maupun muamalah, agar dapat dirumuskan menjadi norma hidup (kaidah konkret) yang dapat dilaksanakan manusia muslim baik sebagai manusia pribadi maupun sebagai anggota kehidupan sosial, disebut ilmu fiqih. Ilmu fiqih terbagi atas fiqih ibadah dan fiqih muamalah. Hasil pemahaman tentang syariat yang disebut hukum fiqih dapat berbeda di suatu tempat dengan tempat lainnya.

Manusia tidak dapat lepas dari hukum dalam setiap sendisendi kehidupannya. Hal tersebut terjadi pula dalam tatanan masyarakat. Cicero menyatakan ubi cocietas ibi us, yang artinya dimana ada masyarakat disitu ada hu-
kum.(Darmawan, 1989:1) Indonesia menganut pluralitas hukum dimana terdapat tiga sistem hukum yang berlaku sebagai hukum positif, yaitu hukum barat, hukum adat, dan hukum Islam.

Aceh merupakan daerah yang memiliki keistimewaan sebab menerapkan syariat Islam sebagai hukum positif mereka. Peraturan perundang-undangan yang berlaku di Aceh berdasarkan Syariat Islam. Hal ini dipengaruhi oleh sejarah, yaitu Islam masuk ke Indonesia berawal di Samudra Pasai, pesisir utara pulau Sumatra, yang kemudian mengalami perkembangan yang pesat. Sekalipun terjadi silih berganti kesultanan Islam di Aceh seperti Kesultanan Samudra, Pasai, dan Aceh, namun spirit Keislaman masyarakat Aceh tidak bisa ditawar-tawar, bahkan antropolog Belanda B. J Boland mengatakan "menjadi orang Aceh identik dengan menjadi muslim". (Yurnal, 2008:199) Walaupun terjadi dinamika dalam masalah fiqh, namunsecara konsisten masyarakat Aceh menerapkan syariat Islam secara formal. Salah satu acuan dalam penerapan Syariat Islam di Aceh yang telah terkodifikasiadalah Qanun al-Asyi (Adat MeukutaAlam) yang dibuat pada zaman pemerintahan Sultan Iskandar Muda. Qanun inilahyang menjadi referensi sebagian besar kesultanan yang ada di Asia Tenggara dalam mene- 
rapkan Syariat Islam diwilayahnya masing-masing.Hukum Islam tersebut kemudian memberikan pengaruh yang besar kepada tatanan kehidupan masyarakat Aceh, sehingga melahirkan hukum positif Aceh yang mengandung syariat Islam.

Sejarah juga mencatat Aceh sejak dulu tidak berhubungan dengan Belanda, namun dipaksa melaksanakan hukum pidana (wetboek van straftrecht) dan hukum perdata (burgerlijk wetboek), sebab merupakan hukum nasional bangsa Indonesia dan Aceh merupakan teritorial Indonesia sehingga wajib tunduk pada hukum tersebut. Namun, pancasila dan UUD 1945 yang menjadi konstitusi Indonesia ternyata berlandaskan agama yang tertuang dalam pembukaan dan batang tubuh UUD 1945 pada sila pertama dalam pancasila. Selain itu dilatarbelakangi oleh sejarah, hampir semua tokoh pejuang Aceh berasal dari kalangan ulama, menjadikan masyarakat Aceh mampu menjalankan dan mempertahankan kedudukan dan harkat serta ciri khas bangsa Indonesia yang religius dan memegang kuat adat dalam tatanan hukum yang berlaku di wilayah mereka.

Berdasarkan ketentuan pasal 5 ayat (1) UUD 1945 dan pasal 18 UUD 1945, propinsi Aceh resmi ditetapkan sebagai daerah istimewa. Kemudian ditetapkanlah UU No. 24 tahun 1956 tentang pembentukan daerah otonomi propinsi Aceh. Propinsi Aceh berdasarkan UU No. 44 Tahun 1999 memiliki empat keistimewaan, yaitu penyelenggaraan kehidupan beragama, penyelenggaraan kehidupan adat, penyelenggaran pendidikan, serta peran ulama dalam penetapan kebijakan daerah.

Pada era reformasi, TAP MPR No. IV tahun 1999 tentang GBHN menegaskan daerah istimewa Aceh sebagai daerah otonomi khusus guna mempertahankan integrasi bangsa dan menghargai kesetaraan dan keragaman kehidupan seni budaya. Selanjutnya GBHN ditindaklanjuti oleh UU No. 22 Tahun 1999 tentang pemerintah daerah dan UU No. 25 Tahun 1999 tentang perimbangan keuangan antara pemerintah pusat dan daerah. Indonesia merupakan negara hukum, sehingga pada tanggal 9 Agustus 2001 ditetapkan UU No.18 Tahun 2001 tentang otonomi khusus daerah istimewa Aceh sebagai propinsi Nanggroe Aceh Darussalam.

Salah satu faktor hukum dan politik yang memperlihatkan konsistensi antara pemerintah pusat dan daerah adalah lahirnya UU No. 18 Tahun 2001 diatas, yaitu realisasi pemberlakuan syariat Islam di Nanggroe Aceh Darussalam dan diperkuat dengan UU No. 11 
Tahun 2006 tentang Pemerintahan Aceh yang secara spesifik mengamanatkan pemberlakuan syariat Islam di seluruh wilayah propinsi Nanggroe Aceh Darussalam. Adanya intrument yuridis tersebut, Negara Kesatuan Republik Indonesia (NKRI) telah memberikan jaminan konstitusi terhadap masyarakat Aceh untuk merealisasikan penegakan syariat Islam, juga menjadi dasar bagi masyarakat Islam yang menghendaki adanya penegakan syariat Islam di wilayah Indonesia lain, baik dalam dimensi publik maupun privat tanpa diskriminatif. Sebagai pelaksana dari undang-undang tersebut lahirlah qanun (perda) No. 10 Tahun 2002, mengenai pembentukan Mahkamah Syar'iyyah yang akan memberlakukan hukum Islam dalam dimensi yang kaffah (totalitas). Juga terbentuknya beberapa lembaga lain sebagai penguat terhadap pelaksanaan dan penegakan Syariat Islam, antara lain Dinas Syariat Islam, lembaga Baitul Mal, dan Majelis Permusyawaratan Ulama.

Keppres No.11 tahun 2003 tentang mahkamah syar'iyyah dan mahkamah syar'iyyah propinsi lahir guna melaksanakan hukum Islam yang menentukan wewenang dari mahkamah syar'iyyah yang selanjutnya ditetapkan beberapa peraturan daerah (qanun). Pelaksanaan syariat oleh mahkamah syar'iyyah diatur dalam Qanun
No.10 Tahun 2002 tentang peradilan syariat Islam dan Qanun No.11 Tahun 2002 tentang pelaksanaan syariat Islam di bidang akidah, ibadah, dan syiar Islam yang salah satu ketentuannya adalah kewajiban berbusana Islami bagi pemeluk muslim di seluruh wilayah Nangroe Aceh Darussalam. Qanun No. 12 Tahun 2002 tentang khamar, Qanun No. 13 Tahun 2003 tentang maisir (judi) dan Qanun No. 14 Tahun 2003 tentang Khalwat. Sampai saat ini ketentuan hukum acara (Qanun Acara Jinayah) mengenai tata cara hukum Jinayah (Qanun Jinayah) tersebut masih dalam proses pembahasan dan finalisasi oleh DPR Aceh bersama Eksekutif Aceh. Pada dewasa ini, karena kedua qanun tersebut belum disahkan sehingga terjadi kekosongan hukum yang membuat tersangka dapat lepas dari jeratan hukum, sehingga dalam Qanun No.10 Tahun 2002 kekosongan ini diatasi dengan tetap memberlakukan KUHP sebagai dasar hukum. Oleh sebab itu mahkamah syar'iyyah selama ini dalam penegakkan dan pengusustan perkara jinayah terhadap tersangka mengalami kesulitan, karena belum ada hukum acara untuk pelanggar syariat di Aceh. Sedangkan KUHP sebagaimana amanah dari Qanun No. 10 Tahun 2002, tidak mengatur secara spesifik hukum aca- 
ranya untuk mengadili pelanggar syariat Islam.

Kebijakan pemerintah Aceh membentuk petugas polisi syariah (wilayatul hisbah) juga telah dilakukan yang berfungsi sebagai pengawas terhadap pelaksanaan syariat Islam. Sekalipun kebijakan tersebut menuai pro kontra, namun masyarakat dan pemerintah Aceh tetap konsisten menjalankannya. Fakta terakhir, pada tanggal $24 \mathrm{Ju}-$ ni 2005 di Kabupaten Bireun, untuk pertama kali penyelenggaraan hukuman cambuk dilakukan oleh penegak hukum membuktikan bahwa kejaksaan telah menjawab keraguan yang selama ini muncul dikalangan pakar dan politisi hukum. Itu berarti bahwa penegakan syariat Islam di Aceh dengan landasan hukum positif tampak semakin jelas, bukan hanya dalam bidang perdata melainkan juga dalam bidang pidana (jinayah). $\mathrm{Hu}-$ kum cambuk bagi pelanggaran khamar, maisir (judi), dan khalwat (zina) terbaca dengan jelas. Ada sebahagian terhukum yang mengakui atas timbulnya kepuasan spiritual.

Penerapan hukum pidana Islam pada mahkamah syar'iyyah mempengaruhi tatanan pola hukum secara keseluruhan di Indonesia, karena penerapan syari'at Islam tanpa dilengkapi ketentuan hukum yang sejajar dan lebih tinggi, hanya menjadi celah para pene- gak hukum untuk melakukan penyimpangan dalam praktiknya. Aceh merupakan daerah yang mendapat legitimasi untuk menerapkan syariat Islam, sehingga hukuman pidana Islam yang ditetapkan seperti hudud, qishah, dan ta'zir terhadap pelaku maksiat dan kriminalitas bukan sekedar simbolis saja. Namun yang menjadi tantangan selanjutnya bagi masyarakat Aceh dalam mempertahankan syariat Islam adalah berlakunya hukum barat di Indonesia, serta kurangnya minat para ulama dan ahli hukum di Indonesia dalam mengkaji secara mendalam dan terarah mengenai syariat Islam dan keberlakuannya di dalam tatanan hukum nasional Indonesia umumnya dan masyarakat Aceh khususnya.

Sejak Aceh memproklamirkan sebagai "negeri syariat" pada tahun 2002, Pemberlakuan dan pelaksanaan syariat Islam di Aceh tidaklah berjalan dengan mulus, melainkan berbagai rintangan dan tantangan terus datang silih berganti. Berbagai "serangan" dan gugatan dialamatkan kepada penerapan syariat Islam di Aceh, baik datangnya dari pihak luar (non muslim) maupun dari pihak dalam (muslim sekuler) sendiri, juga dari pegiat HAM internasional. "Serangan" dan gugatan yang tiada henti tersebut terus akan adaselama penerapan dan penegakan syariat 
Islam berlangsung di Aceh. Dengan dalih HAM, para penentang syariat Allah dengan tegas menentang penerapan syariat Islam di Aceh. Tujuannya adalah untuk mendeskriditkan syariat Islam dan tidak rela syariat Islam diterapkan di Aceh. Dengan berbagai argumentasi dan dasar hukum penegakan syariat Islam di Aceh sampai saat ini masih berlaku dan berjalan sebagaimana yang diharapkan.

Berkaitan dengan hal ini, Allah SWT telah mengingatkan kita terhadap pihak-pihak yang tidak rela dan senang dengan syariat Islam, sebagaimana firman-Nya, "Dan orang-orang Yahudi dan Nasrani tidak akan rela kepadamu (Muhammad) sebelum engkau mengingkuti agama mereka.." (AlBaqarah: 120). Perasaan tidak suka terhadap syariat Islam juga telah merasuk ke dalam sanubari orang Islam yang sekuler, yang merupakan notabene murid dan pengikut setia misionaris dan orientalis. Apa yang disebutkan dalam al-Quran tersebut telah terbukti sejak dulu sampai saat ini, bahkan sampai hari Kiamat nantinya.

Untuk menepis berbagai tuduhan negatif dan syubhat terhadap syariat Islam yang mulia, maka menurut hemat penulis, perlu dijelaskan visi dan misi syariat Islam secara persuasif, konfrehensif dan argumentatif. Juga menso- sialisasikan maksud dan tujuan Islam diturunkan kepada seluruh umat manusia, sehingga tidak terjadi kesalahan dalam memahami syariat Islam apalagisampai mencurigai.

Menanggapi desakan Amnesty International dan para pegiat HAM agar Pemerintah Indonesia menghentikan penerapan hukum cambuk yang berlaku di Provinsi Nanggroe Aceh Darussalam (NAD). (Serambi, 22 Mei 2011) Perlu dijelaskan dan disampaikan beberapa hal sebagai berikut:

Pertama, tuduhan Amnesty International negatif terhadap hukuman dalam syariat Islam seperti cambuk melanggar hak asasi manusia adalah tidak mendasar sama sekali. Bahkan tuduhan Amnesty International tersebut melanggar HAM umat Islam, dimana umat Islam berhak dan bebas mengamalkan agamanya tanpa larangan dan intimidasi. Syariat Islam di Aceh adalah hasil konstruksi sosial dan keinginan rakyat Aceh yang hanya diterapkan dan diperuntukkan bagi umat Islam di Aceh, bukan untuk umat non Islam dan umat Islam di luar Aceh. Perlu dicatat bahwa pemberlakuan syariat Islam di Aceh yang sekarang sudah menjadi hukum positif tidaklah diperoleh dengan begitu saja, tetapi melalui sebuah perjuangan panjang yang telah banyak mengorbankan nyawa, darah, harta, kehormatan dan 
air mata rakyat Aceh. Sehingga pemerintah R.I untuk menyelesaikan perseturuan panjang antara Aceh dan Jakarta, pemberlakuan syariat Islam adalah salah satu dari butir perdamaian yang disepakati antara Aceh dan Jakarta.

Kedua, salah satu point dari Deklarasi Umum Hak Asasi Manusia bahwa setiap manusia dijamin untuk bebas beragama dan melaksanakan keyakinan agamanya, yang ini juga dijamin oleh UUD 1945 tentang kebebasan beragama dan melaksanakan keyakinan agamanya, sehingga pelaksanaan Syariat Islam di Aceh (secara legal formal telah diamanahkan oleh Undang-Undang Negara Kesatuan Republik Indonesia), baik dalam dimensi privat dan publik merupakan pengejawantahan dari kebebasan beragama. Oleh karena itu tuduhan melanggar Hak Asasi Manusia (HAM) dan meminta hukuman cambuk di Aceh dicabut menjadi tidak beralasan.

Ketiga, Amnesty International menuduh hukuman cambuk bertentangan dengan HAM. Namun, yang menjadi persoalan, HAM mana yang dimaksud Amnesty International? Karena, konsep HAM dalam paradigma Islam berbeda dengan konsep HAM dalam paradigma Barat yang cederung mengasihani si pelaku maksiat (kriminal), tanpa mengasihani korban kriminal. Kalau HAM model barat ini yang dimakksud, maka Amnesty International telah salah sasaran dalam menuduh. Karena, orang Aceh itu muslim dan daerah Aceh merupakan daerah yang resmi menerapkan syariat Islam. HAM model barat tidak boleh dipakai di Aceh, karena bertentangan dengan syariat Islam yang mulia.

Keempat, Amnesti International telah mengintervensi urusan agama Islam, maka Amnesty International telah melanggar HAM pula. Padahal, Islam tidak pernah mencampuri urusan agama lainnya. Bahkan Islam memberi kebebasan bagi agama lain untuk beragama dan beribadah sesuai dengan agama dan kepercayaannya (AlKafirun: 6 dan Al-Baqarah: 256). Oleh karena itu, usulan Amnesty International sepertinya sudah terlalu jauh 'mencampuri" urusan keyakinan agama seseorang dan kekuasaan sebuah bangsa. Ini jelas melanggar HAM umat Islam dan berbagai aturan yang berlaku di negara RI seperti UUD 1945, UU no 44 tahun 1999, UU no 11 tahun 2006, dan sebagainya.

Kelima, Salah satu alasan yang dikemukakan oleh pegiat HAM bahwa cambukan bisa mengakibatkan cedera jangka panjang atau permanen,", tidaklah beralasan, mungkin para pegiat HAM tidak memperoleh informasi yang utuh bagaimana mekanisme dan 
proses pelaksanaan hukum cambuk di Aceh. Kalau pun hukuman tersebut menimbulkan rasa sakit dan malu, itu merupakan bagian dari efek jera yang ingin dicapai dari suatu proses penerapan hukuman bagi pelaku kejahatan.

Keenam, konsekuensi ketika sudah memilih Islam sebagai agama, maka suka tidak suka aturan hukum-hukum agama tersebut harus diberlakukan kepada yang bersangkutan. Dan ini sangat selaras dengan kebebasan beragama. Baru melanggar HAM kalau kepada pemeluk agama selain Islam dipaksakan untuk menggunakan hukum Islam, suatu aturan tidak akan jalan kalau tidak diawali dengan ketegasan dan sanksi.

Bagaimanapun juga, pemberlakuan Syariat Islam di Aceh melalui Undang-Undang nomor 44 tahun 1999 tentang penyelenggaraan keistimewaan Aceh dan Undang-Undang nomor 11 tahun 2006 tentang Pemerintahan Aceh adalah sebuah amanah undangundang yang harus dijalankan dan ditegakkan. Pelaksanaan dan penegakkan syariat Islam di Aceh menjadi sejarah yang harus dipertahankan dan diteruskan dari generasi ke generasi berikutnya. Pemberlakuan Syariat Islam di Aceh merupakan nikmat Allah yang patut disyukuri.

Oleh karena itu, pemerintah Aceh dan pemerintah pusat harus komitmen dalam menegakkan syariat di Aceh dan tidak terpengaruh dengan gugatan dan intervensi pihak luar terhadap syariat Islam yang berlaku di Aceh.

Pemerintah diharapkan pula dapat memberikan jawaban dan klarifikasi yang profesional dan proposional terhadap desakan Amnesty International dan para pegiat HAM. Kepada pihak amnesty International dan pegiat HAM untuk menghormati agama Islam, undang-undang yang berlaku di negara R.I dan rakyat Aceh yang beragama Islam dalam menegakan syariat Islam.

\section{KESIMPULAN}

Konsep HAM dalam Islam bermuara kepada ajaran tauhid, segala aktivitas kehidupan manusia selalu disandarkan pada ajaran tauhid. Melalui pemahaman ajaran tauhid akan lahir sikap menempatkan diri sebagai hamba Allah yang memiliki pengabdian kepadaNya. Konsep HAM dalam Islam tentu saja berbeda dengan konsep yang terdapat dalam HAM Barat, dalam Islam sentral keseluruhannya adalah Allah Swt. Sedangkan dalam konsep HAM Barat sentral individu lebih dominan dari yang lainnya.

HAM dalam Islam memiliki keterbatasan dan tidak absolut sebagaimana kebebasan yang terdapat dalam HAM Barat. Kebebasan 
dan hak asasi dalam Islam selalu dikaitkan dengan kewajiban asasi. Dalam Islam antara hak dan kewajiban memiliki kedudukan yang seimbang. Islam tidak menonjolkan hak dan mengabaikan kebawajiban, demikian sebaliknya.

Penerapan syariat Islam di Aceh, kiranya prinsip-prinsip HAM dalam al-Qur'an dan al-Hadits terus dipelajari dan diteliti kembali sehingga prinsip tersebut akan sesuai dalam penerapan syariat Islam ditengah-tengah masyarakat Aceh, sehingga gugatan-gugatan terhadap penegakan syariat Islam di Aceh dapat diatasi dengan baik.

Penegakkan syariat Islam di Aceh merupakan hak kebebasan dasar bukan saja tidak dilarang, melainkan dilindungi oleh Negara Indonesia. Legitimasi penegakan syariat Islam didasarkan pada HAM Internasional dan beberapa Konvenan Hukum Internasional seperti Konvenan DUHAM 1948, konvensi mengenai hak-hak sosial, ekonomi, dan budaya (ICCESR) 1996 dan konvensi internasional tentang hak-hak sosial dan politik (ICCPR) 1996. Secara konstitusional UUD 1945 hasil amandemen 1999-2002 juga telah memperkuat argumen hukum internasional. Konsekuensinya negara dan pemerintah Republik Indonesia berkewajiban untuk tidak saja memberikan perlindungan dan perlakuan yang adil dan proposional, melain- kan juga memberikan dukungan terhadap penegakan syariat Islam di Aceh sebagai wahana yang memberikan penguatan terhadap Negara Kesatuan Republik Indonesia.

Realisasi penegakan syariat Islam di Aceh telah menjadi fenomena global yang tidak lagi terpancang pada ada tidaknya suatu negara berlabelkan Negara Islam. Secara gradual sesuai kapasitas umat di Aceh, dengan spirit HAM Internasional telah terbukti bahwa ajaran Islam di bidang ekonomi, pendidikan dan sistem hukum dan politik telah saling mengisi dan memberi keuntungan. Dampaknya secara langsung terhadap perjuangan penegakan syariat Islam di Aceh terlihat pada perjuangan melalui lembaga legislatif dan partai politik, dan perjuangan yang panjang hingga sampai kemeja perundingan secara damai.

Sistem pemerintahan dan otonomi yang berlaku di Aceh telah memberikan pelajaran berharga bahwa Negara Kesatuan Republik Indonesia telah sangat terbuka dan sukarela memberikan keistimewaan bagi Aceh untuk melakukan penegakan syariat Islam berdasarkan UU No. 18/2001, dan telah ditindak lanjuti dengan qanun No. 11/2002, danUU No. 11/2006, tentang Pemerintahan Aceh. 


\section{DAFTAR PUSTAKA}

A, Muhammad, 1960, Tafsir alManar, Maktabah al-Qahirah, Cairo.

'Audah, A., Q, t.t, at-Tasyri' al-Jina'i al-Islami, Jilid I, Dar al-Kutub 'Araby, Bairut.

An-Naim, A., A. 1994, Dekosentrasi Syariah, Wacana Kebebasan Sipil, Hak Azasi Manusia dan Hubungan Internasional dalam Islam, terj. Yogyakarta, LkiS

An-Naim, A., A. 1996, Human Rights in the Muslim World, dalam Henry Steiner and Philip Alston, Internasional Human Rights in Contex: Law and Politics Moral, Oxford, Claredon Press.

Al-Maraghy, A., M. t.t, Tafsir alMaraghy, Cairo.

As-Shan'any, 1970, Subulul asSalam, Mustafa al-Baby al-Halaby, Mesir.

Audah, A., Q. 1977, At-Tasyri' alJina'iy al-Islamy, Cet III, Cairo.

Brownlie, J. 1971. Basic Document on Human Rights, Oxford, Claredon Press.

Prinst, D. 1989, Hukum Acara Pidana,Suatu Pengantar, cet. Kesatu, Penerbit Djambatan, Jakarta.

Daud, A., M. 2006, Hukum Islam: Pengantar Ilmu Hukum dan Tata Hukum Islam di Indonesia, cet. Ketiga belas, PT. Raja Grafindo Persada, Jakarta.
Hanafi, A., 1980, Azas-azas Hukum Pidana Islam, Bulan Bintang, Jakarta.

Ddzajuli, H.A. 2003, Fiqh Siyasah, cet. Kedua, Prenada Media,Bandung.

Ismail, S., M. 1998, Ushul al-Fiqh, Tarikhuh wa Rijalul, Dar al-Salam, Mekkah.

Lerner, N. 1971, Religious-Human Rights Under the United Nations, USA.

Muadudi A., 'A. 1975, The Islamic Law and Constitution, Pakistan Islamic Publications.

'Asyur, M., T. 2006, Maqashid asySyariah Islamiyah, Darusslam, Tunisia.

Nasr, S., H. 1986, Politik, Hukum dan Hak Asasi Manusia, Pustaka Firdaus, Jakarta.

Pannikar, 1996, Is the Nations of Rights a Western Concept? Dalam Henry Steiner and Philip Alston, International Human Rights in Contex: Law an Politics Moral, Oxford, Claredon Press

Rahman, F. 1978, Islam dan Hak Asasi Manusia, Pustaka, Bandung.

Robertson A.H. and J.G. Merrils, 1992, Human Rights in the World: An Introduction to the Study of the International Protection of Human Rights, New York, Manchester University Press. 
Sabiq, S. 1977, Fiqh as-Sunnah, Dar al-Fikr, Bairut.

Steiner, Henry and Philip Alston, 1996, International Human Rights in Contex: Law an Politics Moral, Oxford, Claredon Press.

Syahar, S. 1996, Asas-asas hukum Islam, cet. Kesatu, Penerbit Alumni, Jakarta.

Syathibi, Abu Ishak, t.t, alMuwafaqat fi Ushul asy-Syari'ah, I, Dar al-Kutub al-'Ilmiyah, Bairut.

Thontowi, J. 2002, Islam, Politik dan Hukum, Yogyakarta, Madyan Press.

Zuhri, M. 1996, Hukum Islam dalam Lintasan Sejarah, cet. Kesatu, Praja Grafindo Persada, Jakarta. 